\title{
Psychoanalysis in Sweden ${ }^{1}$
}

\section{Per Magnus Johansson (Göteborg)}

Summary: Some of the ideas of Sigmund Freud were preceded in a literary form by the Swedish writer August Strindberg in the late $19^{\text {th }}$ century. Psychoanalysis itself was introduced to Sweden about a decade into the $20^{\text {th }}$ century by two rivalling pioneers, the doctors Emanuel af Geijerstam and Poul Bjerre. After a slow start, the Danish-Norwegian Psychoanalytical Society and the FinnishSwedish Psychoanalytical Society were formed in 1934 in Stockholm. The same year, Ericastiftelsen [The Erica Foundation], a psychotherapeutic clinic for children, was founded by Hanna Bratt. Five years later, in 1939, also in Stockholm, the organization that was to become St. Lukasstiftelsen [The Saint Luke's Foundation] was founded. It has been, and still is, an association that has trained psychodynamic psychotherapists, with a focus on existential, religious and philosophical questions. Today, St. Luke's tries to be up-dated from an academic standpoint. During the Second World War, several important psychoanalysts came to Sweden, for example René de Monchy, Lajos and Edith Székely, and Stefi Pedersen. Few Swedes have contributed to the international psychoanalytic literature. However, Ola Andersson's doctoral dissertation ("Studies in the Prehistory of Psychoanalysis," 1962) and the historian Gunnar Brandell's essay ("Freud, a Man of His Century," 1961) have had an international impact. In the last two decades, an authorized and carefully edited translation of Freud's collected works has been published by Natur och Kultur, and the history of psychoanalysis in Sweden has been written at the University of Gothenburg. Since 1990, several Stockholm based Swedish psychoanalysts have published articles in the journal Divan about the relationship between psychoanalysis and culture. As a result of a recent interest in the work of Jacques Lacan, and French psychoanalysis, philosophy and literature, the journal Psykoanalytisk Tid/Skrift was founded in 2002, in Gothenburg. Since 2011 the journal is called Arche. The largest organized group of psychoanalysts in Sweden today is the Swedish Psychoanalytical Association (SPAF), which has about 225 members. Since 2008, it no longer has the right to license psychotherapists, a situation that reflects the position of psychoanalysis outside the mainstream of psychiatric health services and academic psychology. Despite the criticism of Freud's thinking from biologically and cognitively 
oriented theoretical standpoints, the interest in psychoanalysis endures, which can be considered a promising and intriguing inconsistency.

Keywords: history of psychoanalysis, Sweden, Strindberg, Sigmund Freud, Jacques Lacan

\section{Sweden and Psychoanalysis}

To some degree, Sigmund Freud's line of thought was anticipated at the end of the $19^{\text {th }}$ century in the work of the famous Swedish playwright and novelist August Strindberg, who wrote penetrating dramas, novels and short stories about a variety of human dilemmas, for example religious misgivings, dreams, loneliness, the relationship between the sexes, and the father and his position in the family. Strindberg studied bigotry, destructive forces and the unconscious motivations of men and women at the turn of the last century. His drama, Fadren (The Father), published in 1887, is an early testimony to the decline of the father's position in Western society, and to the manner in which the family structure was disintegrating. He sent the book to Friedrich Nietzsche. He corresponded with Nietzsche in French and felt a special kinship with him. Strindberg focused on the question of whether a man can really know for certain if he is in fact the father of a particular child. Or is there always a doubt? He paints the portrait of a man tortured by the suspicion, instilled by his wife, that the child he loves and thinks of as his own is, in fact, the child of another man. Strindberg's drama ends with the death of the father who, in his doubt, rage and despair, has been declared mentally ill by his wife, his physician and a clergyman. Strindberg's play illustrates how the issue of the recognition of the father is essential to the understanding of the human being. Strindberg also emphasized the importance of dreams. He maintained that the relationship between dreams and reality is complex. For Strindberg, there was neither time nor place in dreams. This is a notion that he shares with Freud, as we know. Dreams, Strindberg writes in "A reminder," the introduction to the drama Ett Drömspel [A Dream Play] (1902), represent an amalgamation of "memories, experiences, free fantasies, absurdities and improvisations." Regarding the persons who appear in dreams, he claims that they can "split, double, multiply, vanish, condense, blur, consolidate." In Strindberg's "A reminder" we encounter a literary way of describing the process of condensation. He explicitly uses the word condensation, and the other words he uses provide good examples of it, from the 
point of view of Freud. It is as if Strindberg senses that the inner and secret life of man can be expressed in dreams.

In a footnote, added in 1917 to The Psychopathology of Everyday Life, Freud pointed out that Strindberg possessed an uncanny faculty for understanding the secret nature of parapraxes. In addition, a Scandinavian contemporary of Strindberg, the Norwegian author and playwright Henrik Ibsen (1828-1906), also dealt with issues similar to those that preoccupied Freud. Ibsen wrote about marriage, relationship and communication between man and woman and took up the theme of the women's liberation movement. He posed the question: how can one understand the hidden message in the exchange between man and woman?

On the one hand, there is no evidence that Strindberg was ever familiar with Freud and psychoanalysis. On the other hand, he admired Otto Weininger and his Geschlecht und Charakter, as well as Karl Kraus and his Die Fackel. Kraus, in turn, gave Strindberg a prominent place in his journal, founded in 1899. As early as 1897, Kraus had seen and reviewed Der Vater [The Father]. Likewise, Weininger had studied this particular play of Strindberg's with keen interest. Kraus turned to Strindberg in connection with Otto Weininger's suicide in 1903; Strindberg also wrote a personal and appreciative obituary of the latter, although it was not published until 1921.

\section{The Earliest Introduction}

Freud's name, along with the names of Josef Breuer, Pierre Janet, and JeanMartin Charcot, appeared for the first time in a Swedish medical journal in 1893. The article, which addressed traumatic neuroses, was written by Frithiof Lennmalm (1858-1924), Professor of Neuropathology. Lennmalm stressed that, on the one hand, it was not possible to draw a clear line between normal and abnormal in regard to neurotic symptoms, and, on the other hand, that neuroses were illnesses just as real as the organic nervous diseases. He recommended hypnosis as the most effective therapy for neuroses: "Illnesses that are caused by ideas can only be cured by other ideas." He referred to Breuer's and Freud's method of finding the ideas that caused the symptoms of hysteria through hypnosis. Nonetheless, Lennmalm cannot be considered a psychotherapist; he was not concerned with the specific methodological problems of psychotherapy.

In 1900, the Swedish author and feminist Ellen Key (1849-1926) published Barnets århundrade [The Century of the Child]. The book was translated into 11 languages (among others English, French, Japanese, Russian and German) and her ideas had an impact in several countries, particularly Germany. She defended the 
right of women to possess independence and a life of their own. In her opinion, society needed to acknowledge the crucial role that women played in giving children a harmonious upbringing. She stressed the importance of allowing children the right to express themselves and condemned the use of corporal punishment in the rearing and education of children. In her opinion, an element she referred to as the "Female Principle" deserved to influence society to a higher degree. She was a dedicated advocate of peace. Key fought for the right of women to vote and to be released from a destructive or unhealthy marriage by means of divorce. She claimed that women had an erotic drive, which must have a place in marriage. Key had discussions and dialogues with writers from abroad as well as from Sweden, such as Rainer Maria Rilke (1875-1926) and August Strindberg.

In 1923, in a note added to On the History of the Psycho-analytic Movement (1914), Freud wrote: "At the present time, the Scandinavian countries are still the least receptive" (p. 34). Psychoanalysis had indeed been introduced to Sweden in an ambiguous way. Two pioneers, Emanuel af Geijerstam (1867-1928), who worked in Gothenburg from 1898 through 1928, and Poul Bjerre (1876-1964), who was active in Stockholm and its immediate vicinity during the first five decades of the 20th century, were united in a common ambivalent attitude towards the new discipline. Geijerstam was a conscientious scientist and psychotherapist, who felt a kinship with Alfred Adler and Carl Gustaf Jung. He went into a didactic analysis with the Norwegian psychiatrist and psychotherapist Johannes Irgens Strömme (1876-1961). As early as 1902, Emanuel af Geijerstam had written about Freud, but after 1916 he repeatedly pointed out that the process known as "anagoge analysis" must be regarded as an improvement of Freud's method. Until his death, he worked alone, without any institutional contact with colleagues. Since he was, after all, primarily a physician, albeit with an interest in psychological questions, he was disinclined to place himself as a disciple of any theoretical master.

Poul Bjerre took over the practice of the physician Otto Wetterstrand (18451907 ) in 1907. Wetterstrand was located in central Stockholm, where he also treated Freud's patient Emmy von N. Both physicians worked in the hypnotic tradition and accepted patients from several European countries. Bjerre met Freud in the beginning of 1911. The same year, he presented a selection of Freud's ideas to the Swedish Society of Physicians, and in 1924 he translated and published two of Freud's articles. Already after their first meeting, Bjerre was preoccupied with the notion that his own ideas were more important than those of Freud. He believed that Freud's - allegedly - mechanistic views were responsible for the latter's failure to understand the significance of "psychosynthesis." Bjerre had contact with 
many artists and writers, and he introduced Freud to Lou Andreas-Salomé in 1913. Bjerre founded a Psychotherapeutic Institution but had, strictly speaking, no followers. He continued to write books and articles, but his work left no impact on psychoanalysis in Sweden or elsewhere. His brother, Andreas Bjerre (1879-1925), interviewed murderers and became a pioneer in the field of criminal psychology.

Thus, during the first three decades of the 20th century, Freud was introduced to Sweden by two physicians, both of whom, in spite of mutual differences, lacked the capacity or were unwilling to embrace Freud's theory as a whole. Moreover, Poul Bjerre and Emanuel af Geijerstam did not work together, but were in fact rivals. There was at this time no psychoanalytic movement in Sweden. During this period Swedish writers and poets took no interest in psychoanalysis. Nor did academic philosophers display any interest in Freud's theories.

\section{Early Development and Opposition}

There were additional sources of opposition to Freud. In the Society of Physicians, the influential psychiatrists Bror Gadelius (1862-1938) and Olof Kinberg (1873-1960) set the tone. The following statement by Professor Gadelius can serve as an example:

Freud has exaggerated the importance of sexuality, and he has reached his views because his clientele in a world city such as Vienna is, in a specific way, predisposed to such exaggerations. It cannot be emphasized too strongly that, aside from the sexual complexes, the importance of which in the aetiology of hysteria I certainly do not deny, other complexes which are affect-laden in a different manner create neuroses and hysteria, and these ideational complexes are related to the «Ich-Triebe». (Svenska läkarsällskapet, 1913, p. 470)

Later, Gadelius also saw the merits of Freud's work. In his textbook of psychiatry, "Det mänskliga själslivet" [The Life of the Human Mind, translated into English in 1933], he wrote:

[d] uring the last decades, the importance of the sexual drives on our mental life has received far greater attention, primarily through the work of Freud and his school. (Gadelius, 1921-24/1989, p. 339) 
In the same year, 1924, the first Swedish translation of one of Freud's books, The Psychopathology of Everyday Life, was published. The book was translated by Emmy von Voigt, born Larsson (1874-1961). She married Georg Groddeck in 1923.

As the interest in psychoanalysis increased in Sweden during the final years of the 1920s and in the early 1930s, so did resistance to it. This was evident in connection with Bjerre's attempt to publish his lecture "The Psychoanalytic Method," in which he presented his most positive evaluation of psychoanalysis and responded to objections that others had raised against it. Normally, lectures conducted for the Society of Physicians were published in the journal Hygiea. But Bjerre's contribution was rejected under the pretext that it was too long. In 1934, Gadelius organized his critique of psychoanalysis in his book Tro och helbrägdagörelse, jämte en kritisk studie av psykoanalysen [Faith and Healing, and a Critical Study of Psychoanalysis].

In the second half of the 1920s, psychoanalysis was also discussed in Clarté, a socialist literary journal that was part of the international Clarté movement. Intellectual proponents of psychoanalysis published their contributions in this journal, impassioned by the idea that psychoanalysis could be an element of a radical political theory and an instrument for social change.

An interest in psychoanalysis in literary circles in the 1930s was also displayed in a new journal, Spektrum. It not only published modernist poetry and prose, it also featured translations of works by psychoanalytic writers, such as Anna Freud, Erich Fromm and Wilhelm Reich. One of the editors was the physician, writer and translator Pehr Henrik Törngren (1908-1965), who also published psychoanalytic contributions of his own. His book Striden om Freud [The Controversy over Freud], 434 pages long and published in 1936, is one of the first theoretical landmarks made by a Swedish psychoanalyst. Törngren, probably the most brilliant of the Scandinavian psychoanalysts during the 30s and the $40 \mathrm{~s}$, was in analysis with Ludwig Jekels (1861-1954). He translated Freud as well as Thomas Mann, and taught for more than fifteen years at an institution for adult education, Kursverksamheten [The Open University]. He maintained contact with Scandinavian physicians by way of the journal Nordisk Medicin [Scandinavian Medicine] and thereby took part in a scientific context. But he was an outsider and later on excluded from the Swedish Psychoanalytic Society (founded in 1934, see below), and, consequently, also from the IPA; he criticized psychoanalysis in a way that was not permitted, regarding the discussion about psychoanalysis and its limits as terminated. The highly admired Swedish poet Karin Boye (1900-1940), who was in analysis in Gothenburg, Stockholm and Berlin, wrote articles for the journal Spektrum and, in collaboration with the Swedish translator and scholar 
Erik Mesterton, translated The Waste Land by T. S. Eliot. She committed suicide in 1940. Spektrum became a melting pot for surrealism and psychoanalysis. During this period, parts of The Interpretation of Dreams and the entire The Future of an Illusion and Civilization and its Discontents were translated into Swedish. This was a time when political efforts with regard to sexual enlightenment and equality ran parallel to the interest in psychoanalysis.

From the mid 1920s on, the Norwegian journalist and agitator, Elise Ottesen-Jensen (1886-1973), devoted her life to a controversial enlightenment campaign. In 1933, she played a part in the creation of the influential organization Riksförbundet för sexuell upplysning, RFSU (The National Swedish Association for Sexual Information). She became its first president and held this post until 1956. She fought for the humanization of the Swedish abortion laws and for the legalization of contraceptives. She was an advocate of sex instruction in school. Her ideas had an impact on Swedish legislation. In 1938, the abortion laws were modified as a result of her influence. Up till then all abortions had been illegal. In 1942, schools were recommended by law to give information in sexual matters to all children. Thirteen years later, sex education in school was made obligatory. Through her assiduous work, a home for single mothers was also created. ${ }^{2}$ She had a close relationship to and an intellectual exchange with several of the psychoanalytical pioneers.

\section{Establishment of a Nordic Psychoanalytical Society}

In August 1931, a group of Nordic clinicians who were interested in psychoanalysis met to discuss the establishment of a psychoanalytic society. Sigurd Naesgaard (1885-1956) from Denmark, Harald Schjelderup (1895-1974) from Norway, Yrjö Kulovesi (1887-1943) from Finland, and Alfhild Tamm (1867-1959) from Sweden, took part in these discussions. In 1934, two groups were formed, Dansk-Norsk psykoanalytisk forening [The Danish-Norwegian Psychoanalytical Society] and Finsk-Svenska Psykoanalytiska Föreningen [The Finnish-Swedish Psychoanalytical Society]. The same year, the poet Gunnar Ekelöf published a collection of poetry, Dedikation [Dedication], in which he made an important reference to Rimbaud. Ekelöf also translated the French surrealists and was familiar with psychoanalysis. Alfhild Tamm, who was the first female psychiatrist in Sweden and, since 1926, a member of the Psychoanalytic Society in Vienna, became chairperson of the Finnish-Swedish Psychoanalytical Society. Driven by ideals in the spirit of the Enlightenment, Tamm fought prejudice regarding masturbation. She had a special interest in speech disorders and worked within the public school 
system with children and teenagers. At the same time, she tried to train the few Swedish physicians who were interested in psychoanalysis. She wrote articles for the daily press and defended and explained the merits of psychoanalysis to the general public. However, the historical circumstances were complicated and the resistance hard and strong. Tamm appears to have lacked the collegial following required to develop a forceful Swedish branch of psychoanalysis.

In the early 1930s, psychoanalysts trained in Central Europe, primarily in Vienna, began to arrive in the Scandinavian countries. Ludwig Jekels, a disciple of Freud's, stayed in Stockholm for almost three years. He experienced this time as difficult and wearing, and he left Sweden with a sense of defeat. He wrote that Swedish psychoanalysts were not sufficiently motivated to acquire new knowledge. According to Jekels, they only pretended to be already practicing psychoanalysis. Jekels was also criticized by some of the Swedish psychoanalysts. He never returned to the capital of Sweden. During the same period, Scandinavians started to travel to Vienna, Berlin, and Zurich to be in analysis with August Aichhorn, Helene Deutsch, Paul Federn, Eduard Hitschmann, Oskar Pfister and others.

\section{Competing Organizations}

While the Nordic psychoanalysts were educating and organizing themselves according to the post-1926 standards of the International Psychoanalytic Association (IPA), alternative psychotherapeutic organizations were established in the Scandinavian countries. These organizations tended to reject certain tenets of psychoanalysis, such as the theories of infantile sexuality and dreams. In 1932, Nordisk psykoanalytisk samfund [The Nordic Psychoanalytical Association] was founded in Norway with, among others, Poul Bjerre from Sweden and Sigurd Naesgaard from Denmark as members. In Denmark, a society called Psykoanalytisk samfund [The Psychoanalytical Association] was established in 1933. Again, Bjerre and Naesgaard took part in this venture, as did Johannes Irgens Strømme from Norway. In this context, we must also call to mind the way psychoanalysis was received in Scandinavia. From the outset several psychotherapeutic societies were founded alongside one another. There was a multitude of theoretical influencesAdler, Jung, and Freud, and psychotherapy inspired by Christian values, were introduced simultaneously. The foundation of Sankt Lukasstiftelsen [The Saint Luke's Foundation] in 1939 is an example of the collaboration between medical doctors and priests. To be precise, the foundation "Serenity and Strength" was founded in Stockholm in March 1939, and in November 1940, it changed its name to the St. Luke's Foundation. St. Luke's started its first local branch in 1946, in Gothenburg. 
It has been, and still is, an association that has trained psychodynamic psychotherapists. It also offers psychotherapeutic treatment. St. Luke's has had a great importance for the psychodynamic tradition in Sweden. At present, in 2015, it has more than 30 local branches all over Sweden.

\section{Influential Psychoanalysts}

In connection with the rise of Nazism and the Second World War, the Dutch psychoanalyst and president of the Dutch Psychoanalytical Society, René de Monchy, (1893-1969) emigrated to Sweden and settled in Stockholm. Prior to this, he had married the Swedish-Jewish psychoanalyst Vera Palmstierna, born Herzog (1901-1947), in Vienna, where both of them participated in seminars with Freud. De Monchy, who was a key person in Dutch psychoanalysis and who was personally acquainted with Freud, played a dominating role during his eight years in Sweden. He wrote articles in English, French, German and Swedish and helped the Swedish Psychoanalytical Society to make an impact on an international scale. Vera Palmstierna de Monchy, his third wife, committed suicide and de Monchy remarried soon afterwards for the fourth time. In 1952, he went back to Holland with his new Swedish wife, Maj de Monchy, a former patient. He left Stockholm with a feeling that there was no future for him in the new country. The Swedish psychoanalysts were once again disappointed and abandoned by a father figure.

Ola Andersson (1919-1990), and the Hungarian psychologist Lajos Székely (1904-1995), were both in analysis with René de Monchy. Székely arrived in Sweden as a Jewish refugee along with his wife, Edith, also a psychoanalyst. He had commenced his analytic training in Holland and Germany and completed it in Sweden. For five decades, he played an important role for Swedish physicians and psychologists in psychoanalytic training. He published articles on creativity and the unconscious in English, French, German, Hungarian, and Swedish. He was a trained experimental psychologist, and in parallel with his psychoanalytical work, sought a position at a Swedish university. However, this was something he never attained and, towards the end of his life, his sense of isolation in relation to the Swedish academic world led him to question his decision to practice psychoanalysis. In retrospect, he felt that it would have been better if he had devoted himself to biological research. In an interview, conducted when he was almost 90 years old, Székely regretted that he had not pursued his neurobiological studies to become a researcher: 
The progress in psychoanalysis is very slow. In effect, it remains in the same spot. I must admit that I still regret not becoming a biochemist. The most marked progress in modern science has been made in biochemistry and molecular biology. (Fenyö, 1991, p. 31)

Lajos Székely had tried to combine experimental psychology with psychoanalysis, as well as trying to incorporate findings in the domain of ethological research into psychoanalytical theory. Székely's interest in research was related to the psychoanalytic clinic, and his penetrating case study of one of his patients is in line with the tradition established by Freud. He tried to increase his knowledge of the conditions for creativity by combining psychoanalysis, experimental psychology, and ethology. In this context, it is worth noting the contrast between Szekely's focus and Freud's own psychoanalytic studies, which aimed at understanding events where something had failed to work. This "failure" could manifest itself in the form of inhibitions or symptoms. Freud, as we know, took the position that he was unable to fully understand creativity, and found himself forced to admit defeat before the question of artistic brilliance.

Another important psychoanalyst who took refuge in Sweden during the same period was Stefi Pedersen (1908-1980). She started her psychoanalytic training at the Psychoanalytic Institute in Berlin. Her first analysis was with Otto Fenichel, whom she followed to Oslo in 1933. In 1943, still on the run from the Nazis, she escaped on foot, accompanied by a group of Jewish children, over a mountain ridge in northern Scandinavia to Sweden. Her second analysis was with René de Monchy. Pedersen became a member of the Finnish-Swedish Psychoanalytic Society, which by then was called the Swedish Psychoanalytic Society. The Swedish group became an independent society in 1943, while the Finnish group was dissolved, due to a lack of interest. The position Pedersen took was that of an independent writer. She felt an intellectual kinship with psychoanalytic thinkers as seemingly different as Alexander Mitscherlich, Erik Homburger Erikson and Margaret Little, with whom she also maintained personal ties. Pedersen published articles and books in German, English, Norwegian, and Swedish on narcissism, humiliation and the psychological consequences of political terror. Her articles reflect her position as an outsider. Pedersen surrounded herself with an informal group of psychoanalysts and creative people.

In August 1943, Tore Ekman (1887-1971) returned to Sweden after almost 20 years in Berlin and Leipzig, where he had held a position as lecturer at the University. Ekman was trained by Therese Benedek (1892-1977) and was close to 
the aforementioned Alfhild Tamm. He had a comprehensive knowledge of Freud's work, which he read in German, and had an influential position in the Swedish Psychoanalytical Society. However, he was rarely published and some of the Jewish Swedish psychoanalysts were, for obvious reasons, critical of his staying in Germany until August 1943. Also, he held an often criticized powerful position in Swedish society, from which his influence was often felt.

A similarly prominent position in Swedish society was held by Carl Lesche (1920-1993). Born in Finland, Lesche was a philosopher of science who moved to Sweden in the early 1950s. Lesche was influenced by the philosophies of Edmund Husserl (1859-1938), Wilhelm Dilthey (1833-1911), and Karl-Otto Apel (born 1922). A primary focus of his work was the nature of psychoanalysis as a scientific discipline. Lesche delineated why, in his view, psychoanalysis belongs to hermeneutics rather than to the natural sciences, and he considered it important to differentiate psychoanalysis from psychotherapy. Lesche attracted disciples who acted as his spokesmen in different situations. They viewed his work as deeply original. For many years he was the leading Swedish psychoanalyst, and he trained some of the most influential third generation Swedish analysts. He was convinced that academic psychology did not recognize the importance of psychoanalysis. He became a member of the Russian-Greek Orthodox Church and collected Gregorian music.

Historically, relatively few Swedish contributions to psychoanalytic thought have had an international impact. Two outstanding exceptions are Ola Andersson's doctoral dissertation, "Studies in the Prehistory of Psychoanalysis" (1962), and the historian Gunnar Brandell's essay “Freud, a Man of His Century”(1961). Andersson uncovered the historical and philosophical context of the development of Freud's ideas up to 1896, that is, to the point when psychoanalysis started to take the form of an independent discipline. He demonstrated Johann Friedrich Herbart's (1776-1841) influence on Freud, and later also carried out original research, leading to the verification of the true identity of Freud's patient, Emmy von N. Ola Andersson and Gunnar Brandell (1916-1994) participated in seminars organized by Professor Wilhelm Sjöstrand (1909-1989) at the Department of Education at Uppsala University. At that time, at Uppsala University, a select group of scholars worked together, and some of the members, like Andersson and Brandell, wrote important texts. This was also the period during which Michel Foucault taught at the same university. 


\section{Psychotherapy for Children}

In 1934, Ericastiftelsen [The Erica Foundation], a psychotherapeutic clinic for children, was founded by Hanna Bratt (1874-1959), a teacher. Eventually, a psychoanalytically oriented program was offered to teachers, paediatric psychiatrists and psychologists who wished to learn child psychotherapy. An early leader of the clinic was Gunnar Nycander (1900-1964), who was trained at the Swedish-Finnish Psychoanalytic Society. He had undergone analysis with Ludwig Jekels and became a medical doctor in 1950. Another psychoanalyst, the physician Gösta Harding (1906-1976), who was trained in Stockholm and in didactic analysis with Tore Ekman, headed the Erica Foundation from 1945. For a brief period of time, he was also the president of the Swedish Psychoanalytic Society. Relatively soon, however, he left the Society, angry and frustrated by institutional conflicts. Both Nycander and Harding wrote books based on empirical material obtained through their work within the psychotherapeutic institution. They tried to combine empirical studies with psychoanalytical theory. In this way, they were also seeking recognition by the university. Up till the $21^{\text {st }}$ century, Nycander's and Harding's successors as leaders of the clinic have all been psychoanalysts. They have all worked to strengthen the relations between the university and the psychoanalytical movement.

\section{Growth, Stagnation, Fluctuation and Renewal}

Since the late 1960s, the former Swedish Psychoanalytic Society, now the Swedish Psychoanalytical Association (Svenska Psykoanalytiska Föreningen, SPAF, see below), has grown steadily; it currently numbers approximately 225 members. In 1982 and 1986, in response to an atmosphere characterized by deadlock and diminished creativity, the IPA made consulting visits to the Swedish Psychoanalytic Society. The members of the Society accomplished little theoretical work, and inner political conflicts had taken the forefront. There was a dogmatic atmosphere and little room for intellectual creativity.

As in other Western European countries, Swedish university departments in the fields of psychology and psychiatry are rarely oriented towards psychoanalysis. A notable exception is the Department of Applied Psychology at Lund University. In the 1940s, a "percept-genetic" methodology for psychological testing was developed there. This technique exploits subliminal perception in order to study anxiety and psychological defence mechanisms. Professors Gudmund Smith, Ulf Kragh, and Alf Nilsson are the most prominent proponents of this tradition. Kragh and Nilsson have been in analysis, and published books and articles in an international academic context, as well as in psychoanalytic journals (cf. Kragh \& 
Smith, 1970). Moreover, Kragh had occasional patients in psychoanalysis while he simultaneously held professorships at the Departments of Psychology in Oslo and in Lund. Smith, Kragh and Nilsson strove to unite the psychoanalytical theory of the defence mechanism with experimental psychology.

Johan Cullberg (born 1934) and Clarence Crafoord (born 1936) have been influential in Swedish psychiatry. Both have dual competencies as psychoanalysts and psychiatrists, and both have been successful writers in the field of applied psychoanalysis. Cullberg, who was awarded a personal professorship from the Swedish government, has also written best-selling textbooks in psychiatry.

In 1968, Margit Norell (1914-2005), one of the members of the Swedish Psychoanalytic Society who was critical of the way in which therapeutic training was set up, left the society and formed the "Swedish Society for Holistic Psychoanalysis and Psychotherapy." Norell was subsequently expelled from the Holistic Society, and continued to work as an independent clinician and supervisor. One of her students, Barbro Sandin, has achieved international fame through her psychotherapeutic work with psychotic patients at Säter, a mental hospital in central Sweden. Norell supervised a group of psychologists who worked with the general hypothesis of repressed memories in their attempts to treat severely disturbed patients. One of them, who between 1993 and 2002 went under the name of Thomas Quick, born 1950, confessed to more than thirty murders under the influence of these psychologists. Due to his confessions, he was convicted of eight murders at various district courts in Sweden. In 2013 a journalist, Dan Josefsson, published a book - Mannen som slutade ljuga [The man who stopped lying]- which led to criticism towards the psychological work supervised by Margit Norell. The idea of repressed memories had influenced the whole legal process in a misleading way. Sture Bergwall, the former Thomas Quick, was finally acquitted of all the murders, and is no longer considered to be a Swedish serial killer.

The Holistic Society found ideological support in the work of neo-Freudians such as Erich Fromm, Frieda Fromm-Reichmann, Harry Stack Sullivan and Otto Allen Will (1910-1993). The tenets of the Society were founded on a critical attitude towards certain aspects of the Freudian theory, for example the theories of infantile sexuality. Up to his death in 1977, Harold Kelman (1906-1977) of New York closely associated with Karen Horney - was an important figure for the Holistic Society. The group joined the non-IPA International Federation of Psychoanalytic Societies in 1972. In recent years, the Holistic Society has oriented itself, step by step, towards the British object-relations school as represented by Melanie Klein and Wilfred Bion, and then returned back to Freud. After a period of collabora- 
tion on scientific matters with the Swedish Psychoanalytic Society, the Holistic Society changed its name to Svenska Psykoanalytiska Sällskapet [The Swedish Psychoanalytical Association] and applied for membership in the IPA on behalf of its 75 members. It became a provisional society at the international congress of psychoanalysis in Nice in 2001.

In recent years, an interest in Jacques Lacan and French psychoanalysis at the liberal arts departments of Sweden's universities was preceded by Swedish translations of texts by a number of French structuralist philosophers and social thinkers, such as Claude Lévi-Strauss, Louis Althusser, Roland Barthes, Michel Foucault, and Julia Kristeva. Only a portion of Lacan's own writings have been translated to Swedish. A small selection, ten percent of his Ecrits, was edited by Iréne Matthis and published in 1989. In 2002, the journal Psykoanalytisk Tid/Skrift was founded. It is currently, without precedent in Sweden, publishing texts from the French psychoanalytical tradition, poetry and French literature. Since 2011 the journal is called Arche.

During the 1970s and 1980s, psychoanalysts from the US and Latin America worked for short periods of time in Gothenburg, Sweden's second largest city, offering training in psychoanalytically oriented psychotherapy. In 1974, Göteborgs Psykoterapi Institut [The Gothenburg Psychotherapy Institute] was founded by Angel and Dora Fiasché, who had previously worked with, among others, Leon Grinberg (1921-2007) and Enrique Pichon-Rivière (1907-1977). Like the Holistic Society in its day, the Gothenburg Psychotherapy Institute is not affiliated with the IPA, even though some of the South American psychoanalysts were IPA members. It continues to maintain a socialist orientation and has approximately 40 members. From the 1990s and onward, a small group of psychoanalysts associated with what is now SPAF is also active in Gothenburg. Outside of these institutions, there is in Gothenburg also a group of intellectuals interested in Freud and the theoretical and clinical work of Jacques Lacan and other French psychoanalysts. Members of this group are affiliated with Freudianska Föreningen [The Freudian Association] and some of its members also work as university-level teachers. The Freudian Association has invited French scholars and psychoanalysts to Sweden.

Another group of psychoanalysts has emerged in the Malmö-Lund region in southern Sweden (the province of Skåne). In the early 1970s, these analysts were largely inspired by Nils Nielsen (1905-1990), an influential Swedish training analyst and his Danish colleague Reimer Jensen (1918-2005). The former worked in Copenhagen between 1949 and 1955 before he settled in Malmö. These analysts - approximately 20 members and 10 candidates - are members of both SPAF 
and the Danish Psychoanalytical Society. Most were trained, or are currently pursuing psychoanalytic training, in Copenhagen, Denmark, and are active in the Psychoanalytical Institute there, as well as in their own informal "Psychoanalytical Society of Skåne.”

\section{A Multifaceted Picture and an Ambiguous Future}

At the recent turn of century, in Sweden as elsewhere, psychoanalysis was exposed to a renewed onslaught of criticism. In light of this, and with regard to Freud's own pessimistic view of psychoanalysis in Scandinavia in 1923, the strength of psychoanalysis in Sweden and the endurance of its followers must be regarded as a promising and intriguing inconsistency. At this time, Swedish psychoanalysts launched the largest psychoanalytic publication project in Sweden yet, an authorized and carefully edited translation of Freud's collected works, published by Natur och Kultur. The history of psychoanalysis in Sweden has been written in a university context; at the Department of the History of Ideas and Theory of Science at the University of Gothenburg. At the same time, the difference between psychoanalysis and psychoanalytically oriented psychotherapy seems to become more and more blurred. Psychoanalysts place more and more stress on the similarity between psychotherapy and psychoanalysis; they also commonly train prospective psychotherapists.

In accordance with a decree of 1985, the state now licenses psychotherapists, which has left a mark on the thinking and actions of Swedish psychoanalysts. In order to obtain the right for psychoanalysts to call themselves licensed psychotherapists, the Swedish Psychoanalytic Society tried to adjust the scope of its training to accommodate the demands of the university system. During a period of about twenty years, the Swedish Psychoanalytic Society gave the title licensed psychotherapist to their candidates. Earlier, during the 1960s, the Swedish Psychoanalytic Society lobbied to obtain governmental licensing for psychoanalysts. These efforts never resulted in any such licensing procedure.

At Swedish universities, cognitive and psychodynamic psychotherapy exist side by side. Clinical psychologists tend to be progressively more eclectic and pragmatic, while academic psychologists take no interest in psychoanalysis, and only a limited interest in psychotherapy in general. Psychiatrists are mainly interested in psychopharmacology, and only in exceptional cases take an interest in Freud. In Sweden, analytic philosophy has exerted an enduring influence on academic philosophers. Discussions between psychoanalysts and philosophers have been few, and of short duration. What is in store for psychoanalysis in Sweden is uncer- 
tain. There are still individuals who are interested in undertaking psychoanalysis. A small number of psychoanalysts find it impossible to meet the demands of prospective patients, while the vast majority complain that they have too few analysands. It is fair to say that the previously held expectation that psychoanalysis would be an effective treatment for a major part of the population has dwindled. A small number of Swedish psychoanalysts write books and articles dealing with essential and urgent issues, while the majority hesitate to put themselves through the arduous task of writing.

Both the Swedish Psychoanalytic Society and the Swedish Psychoanalytical Association (since 2010 merged under the name of the Swedish Psychoanalytical Association, SPAF) were deprived of the right to train licensed psychotherapists in 2008. The major psychoanalytic institutions in Sweden lost their legitimacy in the state system. Naturally, this created a new theoretical and political discussion within the consolidated SPAF concerning the role of psychoanalysis and its relationship to the academic training of psychodynamic psychotherapists. Some members perceived the loss of licensing rights as a relief and liberation, while others saw it as a loss of prestige that entailed a risk of negative consequences for SPAF and for the future of psychoanalysis in Sweden.

Some candidates who are in training as psychoanalysts in SPAF since it lost its licensing rights, and who are neither medical doctors nor psychologists, have felt it necessary to start other training programs for psychotherapists, which have licensing rights, in parallel with their training as psychoanalysts. At present, SPAF is striving for authorization to offer individual courses at the Stockholm University for psychologists who want to become specialists in clinical psychology. The collaboration between the Department of Psychology at Stockholm University and SPAF has become more fruitful and rich during the last decade.

The candidates who are neither medical doctors nor psychologists - one or two of the ten candidates who are accepted every other year - have doctorates from the arts faculties. The decision to accept candidates who are not medical doctors or psychologists has been a subject of discussion within SPAF. Another point of lively debate is the question of how important it is for SPAF that psychoanalysts and psychoanalysis have a place in the university. The Nordic psychoanalytical associations that are associated with the IPA have organized meetings to strengthen the position of psychoanalysis in the university through common efforts.

The interest in applying for training as a psychoanalyst decreased in the beginning of the 2000s, compared with the large interest at the end of the 1960s, and during the 1970s, 1980s, and the beginning of the 1990s. Every other year, 
SPAF accepts ten candidates. In 1989 there were 120 applicants and at present, in 2015, there are 30 .

Today, in 2015, the perception is that there is an increasing interest. In general, SPAF is successful in finding enough suitable candidates for training as psychoanalysts. The arrangement with the Stockholm County Council, which meant that the clinical work of the candidates was subsidized by the Council, has ended. SPAF maintains the principle that the training candidate should meet three analysands four times per week. There are discussions that the number of analysands could be reduced to two. At the same time, one can trace a tendency within SPAF to be less categorically focused on evaluating the essence and quality of the psychoanalytic treatment solely based on the number of sessions per week. Nonetheless, SPAF defends the importance of candidates meeting the analysand four times per week.

Concerning the theoretical orientation within SPAF, the interest in Donald D. Winnicot remains large, and this has been the situation for a long time. The interest for Melanie Klein is on the wane, while the study of Sigmund Freud's work for obvious reasons remains fundamental in the training. There is an increasing interest in French psychoanalysis, not least for Jean Laplanche and André Green. Among the candidates in training at the moment of writing, 2015, there is an interest in the modern attachment theory. A small group of elderly psychoanalysts, who are also physicians, show an interest in neuropsychoanalysis. There are some, but very few, psychoanalysts within SPAF who consider it possible to practice cognitive behavioral therapy parallel to psychoanalysis with suitable patients.

The somewhat older, well-established psychoanalysts in SPAF work mostly in private practice, while the younger ones combine work in the public sector with private practice.

The climate within SPAF has become more open during the past decade. There is a concern that too few of the young psychoanalysts have the necessary courage to commit wholeheartedly to practicing psychoanalysis. There is also a discussion within SPAF about the danger that the training analysts who are medical doctors have too much power and influence. This critical standpoint emphasizes the overhanging risks for conflicts of interest and a concentration of power. In line with this, there are psychoanalysts within SPAF who advocate that SPAF's activities should be more transparent and open.

There is also an ongoing discussion about the relationship between psychoanalysts who are medical doctors and those who are psychologists, a discussion that has in principle always been present in SPAF, as well as in other countries where 
psychoanalysis has taken root. The discussion that Sigmund Freud started in 1926 in his text about lay analysis continues in different ways in different countries.

Some psychoanalysts of SPAF propose that the most constructive aspects of the university, in other words an intellectual and critical discussion, should gain more ground in SPAF.

As mentioned previously, in 2010 the Swedish Psychoanalytical Association (the former Holistic Society) joined with the Swedish Psychoanalytic Society to become what is now Svenska Psykoanalytiska Föreningen [The Swedish Psychoanalytical Association], SPAF. The merging of the two groups has essentially worked well and has vitalized SPAF.

The international tendency to debate the value of psychoanalysis is also a part of the Swedish situation. Intellectuals, scholars in the humanities and artists are still inspired by psychoanalysis. But the resistance that has been present during more than a century is still powerful and is a part of the psychoanalytical condition. This is the case in Sweden, as elsewhere. Today, when almost all psychological and psychiatric theories and praxes are subject to evaluation within the evidence paradigm, psychoanalysts are by necessity invited to state their case. The so-called crisis is also an opportunity.

\section{Bibliography}

Andersson, O. (1962). Studies on the Prehistory of Psychoanalysis. Stockholm: Svenska Bokförlaget.

Brandell, G. (1970). Freud och hans tid [Translation: Freud and His Time]. Stockholm: Bonniers.

Fenyö, Egon (1991). "Lajos Székely berättar”. [Translation: Lajos Székely recounts]. The internal journal of the Swedish Psychoanalytic Society, Bulletinen 2, 10. Freud, S. (1914). On the History of the Psychoanalytic Movement, SE,14, pp. 7-66. Gadelius, B. (1921-24/1989). Det mänskliga själslivet [Translation: The Life of the Human Mind] vols. I-IV. Stockholm: Hugo Gebers förlag.

Hanson, T. (1996). Karl Kraus och Strindberg [Translation: Karl Kraus and Strindberg]. Göteborg: Göteborgs Universitet.

Johansson, P. M. (1999). Freuds Psykoanalys Band 1 Utgångspunkter [Translation:

Freud's Psychoanalysis Volume 1 Points of Departure]. Göteborg: Daidalos. Johansson, P. M. (1999). Freuds Psykoanalys Band 2 Arvtagare i Sverige [Translation: Freud's Psychoanalysis Volume 2 Heirs in Sweden]. Göteborg: Daidalos. 
Johansson, P. M. (2003). Freuds Psykoanalys Band 3 Arvtagare i Sverige [Translation: Freud's Psychoanalysis Volume 3 Heirs in Sweden Part 2.]. Göteborg: Daidalos.

Johansson, P.M. (2009). Freuds psykoanalys Band 4 Inblickar i psykiatrins och den psykodynamiska terapins historia i Göteborg 1945-2009 [Translation: Freud's Psychoanalysis Volume 4 Insights in the History of Psychiatry and Psychodynamic Therapy in Gothenburg 1945-2009]. Göteborg: Daidalos

Johansson, P. M. (2014). Psykoanalys och humaniora. [Translation: Psychoanalysis and the Humanities]. Göteborg: Daidalos.

Kragh, U. \& Smith, G. (1970). Percept-Genetic Analysis. Lund: Gleerups.

Lennmalm, F. (1893). ”Om de så kallade traumatiska neuroserna” [Translation: On Traumatic Neuroses]. Stockholm: Hygiea.

Svenska Läkarsällskapet (1913). "Förhandlingar vid Svenska Läkarsällskapet" [Translation: Minutes of the Swedish Society of Physicians] Stockholm.

\section{Annotations}

1 Thanks to Johannes Nordholm for his constructive work on the article.

2 Towards the end of her career, Ottesen-Jensen became internationally famous. She propagated the knowledge she had acquired in Sweden in matters of family planning. The International Planned Parenthood Federation was founded in1953; Elise Ottesen-Jensen became its first president. 